\title{
Interaction of $\beta$-amyloid(1-40) peptide with pairs of metal ions: An electrospray ion trap mass spectrometric model study
}

\author{
Gabi Drochioiu ${ }^{\text {a, } *}$, Marilena Manea ${ }^{b}$, Mihaela Dragusanu ${ }^{b}$, Manuela Murariu ${ }^{c}$, Ecaterina Stela Dragan ${ }^{c}$, \\ Brandusa Alina Petre ${ }^{b}$, Gabor Mezo ${ }^{d}$, Michael Przybylski ${ }^{b}$ \\ a AL. L. Cuza University, Biochemistry Group, 11 Carol I, Iasi-700506, Romania \\ b University of Konstanz, Department of Analytical Chemistry and Biopolymer Structure Analysis, 78457 Konstanz, Germany \\ ' Petru Poni Institute of Macromolecular Chemistry, 41a Gr. Ghica Voda Alee, Iasi-700487, Romania \\ ${ }^{2}$ Research Group of Peptide Chemistry, Organic Chemistry Department, Hungarian Academy of Sciences, Eötvös L. University, Budapest, Hungary
}

Keywords:

Amyloid B-peptide

Metal ion-peptide complex

Alzheimer's disease

ESI ion trap MS

\begin{abstract}
A B S T R A C T
The stoichiometries and the affinity toward simple and paired metal ions of synthetic amyloid- $\beta(1-40)$ peptide $(A \beta 1-40)$ were investigated by electrospray ion trap mass spectrometry (ESI-MS), circular dichroism (CD), and atomic force microscopy (AFM). The results lead to the working hypothesis that $\mathrm{pH}$-dependent metal binding to $A \beta 1-40$ may induce conformational changes, which affect the affinity toward other metals. A significant copper and zinc binding to $A B 1-40$ peptide at $\mathrm{pH} 5.5$ was found, whereas nickel ions commonly bind to each molecule of $\beta$-amyloid peptide. Some complexes of $A \beta 1-40$ with more than one nickel ion were identified by ESI-MS. In addition, nickel ions proved to enhance $A \beta$ oligomerization. On increasing $\mathrm{pH}$, up to 12 ions of zinc may bind to a single $A \beta$ molecule. Under the same $\mathrm{pH}$ and concentration conditions, the binding pattern of the independent copper and silver ions to $A \beta 1-40$ was different from that of the equimolecular mixture of the two metal ions. One might assume that some conformational changes due to water loss altered the capacity of $A B$ peptide to bind certain heavy metal ions. As a consequence, coppersilver interaction with the binding process to $A(31-40$ became highly complex. A competition between silver and nickel ions for $A B 1-40$ binding sites at high $\mathrm{pH}$ was also observed. New strategies were proposed to identify the characteristic signals for some important metal ion-peptide complexes in the spectra recorded at high $\mathrm{pH}$ or high concentrations of metal ions. To explain the formation of such a large number of high meta ion- $A B$ complexes, we took into consideration the participation of both histidine residues and free amino groups as well as carboxylate ones in the binding process. Finally, CD and AFM studies supported the mass spectrometric data.
\end{abstract}

\section{Introduction}

Electrospray-ionization mass spectrometry (ESI-MS) and circular dichroism (CD) spectroscopic investigations have confirmed that some sites of $\beta$-amyloid peptide $(A \beta)$ are able to specifically bind metal ions $[1,2]$. Metal ions may interact with both amyloid precursor protein (APP) and $A B$ to potentate Alzheimer's disease by participating in the aggregation of these normal cellular proteins and in the generation of reactive oxygen species [3-5]. These metals are normally found at high concentrations in the regions of the brain most susceptible to $A D$ neurodegeneration. Lowering $C u$ concentrations can downregulate the transcription of APP, showing that APP and $A B$ form part of the $C u$ homeostatic machinery in the brain [6]. $A \beta$ peptide, which is over accumulated in the $A D$ brain, can efficiently generate reactive oxygen species in the presence of the transition metals [7]. In fact, increased brain metal levels have been associated with normal aging and a

\footnotetext{
* Corresponding author.

E-mail address: gabidr@uaic.ro (G. Drochioiu).
}

variety of diseases, including Alzheimer's disease (AD) [8]. AB has antioxidant properties, and at low levels, it has trophic rather than toxic properties and these protective effects have been attributed to the antioxidant properties of metallated $A \beta$ [9]. The $\beta$-amyloid plaques that are one of the pathological features of Alzheimer's disease are composed of amyloid- $\beta$ peptides and are highly enriched in metal ions such as $\mathrm{Zn}, \mathrm{Fe}$ and $\mathrm{Cu}[10,11]$. High concentrations of $\mathrm{Zn}^{2+4}$ and $\mathrm{Cu}^{2+4}$ are released during neurotransmission, which might explain why $A B$ precipitation into amyloid commences in the synapse $[12,13]$. Contrary, the addition of low levels of zinc induces protease-resistant aggregation and precipitation of synthetic $A \beta$ [14]. Besides, zinc ions afford protection against $A B$ toxicity at low concentrations and enhance toxicity at high concentrations [15]. Copper and iron also induce peptide aggregation that is increased at acidic $\mathrm{pH}$ [16]. The involvement of metal ions as a potential key factor towards conformational modifications and aggregation of amyloid is widely recognized [17]. Circular dichroism (CD) studies indicated quite minimal ordering of the main-chain with $\mathrm{Zn}^{2+}$ or $\mathrm{Cd}^{2+}$ addition and that $\mathrm{Zn}^{2+}$ coordination is distinct from that of $\mathrm{Cu}^{2+}$ ions [18]. Copper, 
iron, and zinc bind $A \beta$, generate an allosterically ordered membranepenetrating oligomer, induce aggregation and give rise to reactive oxygen species [19]. Iron(II) or iron(III) blocks Cu-mediated neurotoxicity in a highly reducing environment [20]; lipophilic ferrous chelators are effective agents for moderating neuronal damage in conditions such as $\mathrm{AD}$ where intracellular oxidative stress plays a significant role in disease pathology [21].

Nevertheless, less is known how toxic and essential metals may influence each other in regard to their retention by the peptides. We considered that a basic treatment of $A B$ peptide containing two heavy metals (copper(II) and silver(I) or silver and nickel(II) might reveal some interactions which take place between these metal ions and proteins within the living bodies under various $\mathrm{pH}$ conditions. Therefore, the aim of the present study is to detail the stoichiometries and binding properties of multiple cooperative metal ion-binding sites on synthetic $A \beta 1-40$. By the introduction of additional methodological strategies the obtained spectra were simplified and some extra information was obtained. It is also our intention to shed some light on the relationship between various metal ions and amyloid peptide, as well as its impact on AD pathology.

\section{Experimental}

\subsection{Reagents}

Triethanolamine, methyl alcohol, silver nitrate, nickel chloride, ferric chloride, zinc chloride, copper sulfate, and mercury chloride were purchased from Merck (Darmstadt, Germany). All stock solutions of metal ions were prepared using MilliQ grade water (18 M 2 ).

\subsection{Synthesis of $\beta$-amyloid(1-40) peptide}

Peptide H-DAEFRHDSGYEVHHQKLVFFAEDVGSNKGAIIGLMVGGVV$\mathrm{NH}_{2}$ (Aß1-40) was synthesized manually, by SPPS, according to the Boc/Bzl strategy using MBHA resin ( $0.5 \mathrm{mmol} / \mathrm{g}$ coupling capacity) as a support. The following Boc-protected amino acid derivatives were used: Boc-Val-OH, Boc-Gly-OH, Boc-Met-OH, Boc-Leu-OH, Boc-Ile-OH, Boc-Ala-OH, Boc-Lys(ClZ)-OH, Boc-Asn-OH, Boc-Ser(Bzl)-OH, BocAsp(OcHex)-OH, Boc-Glu(OcHex)-OH, Boc-Phe-OH, Boc-Gln-OH, BocHis(Bom)-OH, Boc-Tyr(BrZ)-OH and Boc-Arg(Tos)-OH.

The protocol of the synthesis was as follows: 1) DCM washing $(3 \times 0.5 \mathrm{~min}) ; 2)$ Boc cleavage using $33 \%$ TFA in DCM $(2+20 \mathrm{~min})$ for the first 5 cleavage steps and 33\% TFA, 3\% anisole in DCM containing $50 \mathrm{mg} \mathrm{L}$-methionine and $10 \mathrm{mg} \mathrm{DTT} / 10 \mathrm{~mL}$ cleavage solution $(2+$ $20 \mathrm{~min}$ ) in order to avoid methionine oxidation; 3) DCM washing $(5 \times 0.5 \mathrm{~min})$; 4) neutralization with $10 \%$ DIEA in DCM $(4 \times 1 \mathrm{~min})$; 5) DCM washing ( $4 \times 0.5 \mathrm{~min}) ; 6$ ) coupling 3 or 5 equiv of Boc-amino acid derivative-DCC-HOBt in DCM-DMF mixture (60 min); 7) DMF washing ( $2 \times 0.5 \mathrm{~min})$; and 8 ) DCM washing $(2 \times 0.5 \mathrm{~min})$. Monitor the coupling steps by ninhydrin assay to assess the presence of free amines. In the case of negative results a new cycle was started. The cycle was repeated from the neutralization step when the colorimetric test indicated ineffective coupling. After assembling the peptide chain on the resin, the $\mathrm{N}$-terminal Boc-protecting group was removed prior to the final cleavage with HF.

\subsection{Deprotection and cleavage of the peptide from the resin with $H F$}

After removal of the N-terminal Boc-protecting group, the peptideresin was neutralized and washed with DCM (4 times) and ethanol ( 2 times, $0.5 \mathrm{~min}$ ). Before HF cleavage the resin was dried in a desiccator overnight. The cleavage of the side chain protecting groups and the detachment of the peptide from the resin by HF was performed in a Teflon apparatus (Peptide Institute, Osaka, Japan). For $1 \mathrm{~g}$ of peptide-resin $10 \mathrm{~mL}$ of liquid $\mathrm{HF}$ was used in the presence of $1 \mathrm{~g} \mathrm{p}$-cresol, $0.1 \mathrm{~g}$ DTT and $0.1 \mathrm{~g} \mathrm{L-cys}$. The cleavage was carried out for $90 \mathrm{~min}$ at $0^{\circ} \mathrm{C}$. After evaporation of $\mathrm{HF}$ (captured in a $\mathrm{CaO}$ - filled tower) the peptide was precipitated with cooled diethyl ether. The mixture of precipitated peptide and resin was filtered and washed 3-4 times with diethyl ether $(30-40 \mathrm{~mL})$ to remove scavengers. The unprotected peptide was dissolved in $10 \%$ acetic acid solution and then lyophilized.

\subsection{Reverse phase high performance liquid chromatography (RP-HPLC)}

Analytical RP-HPLC was performed on a Knauer system (H. Knauer, Bad Homburg, Germany) using an analytical Phenomenex Jupiter $\mathrm{C}_{4}$ column $(250 \times 4.6 \mathrm{~mm}$ I.D.) with $5 \mu \mathrm{m}$ silica ( $300 \AA$ pore size) (Torrance, $\mathrm{CA})$ as a stationary phase. Linear gradient elution $(0 \mathrm{~min} 0 \% \mathrm{~B} ; 5 \mathrm{~min} 0 \% \mathrm{~B}$; $55 \mathrm{~min} 100 \% \mathrm{~B})$ with eluent $A(0.1 \%$ TFA in water) and eluent $B(0.1 \%$ TFA in acetonitrile-water $(80: 20 \mathrm{v} / \mathrm{v})$ ) was used at a flow rate of $1 \mathrm{~mL} / \mathrm{min}$ at ambient temperature. Peaks were detected at $220 \mathrm{~nm}$.

\subsection{ESI ion trap mass spectrometry}

Electrospray ionization mass spectrometric experiments and tandem mass spectrometry were carried out on a Bruker Daltonics Esquire 3000Plus (Bremen, Germany) ion trap mass spectrometer. Spectra were acquired in the $200-2000 \mathrm{~m} / \mathrm{z}$ range. Samples were dissolved in a methanol/water $1: 1(\mathrm{v} / \mathrm{v})$ solvent mixture, containing $0.1 \%$ acetic acid, and the $\mathrm{pH}$ was maintained at 5.5 with acetic acid or triethanolamine. Binding of individual metal ions to $\beta$-amyloid peptides was studied by ESI ion trap MS at pH 5.5, at a peptide concentration of $10 \mathrm{pmol} / \mu \mathrm{L}$ and 1:10 peptide:metal ion ratio. The competition of various metal ions towards the binding sites of $A \beta$ peptide was investigated at a 1:5:5 molar ratio (AB1-40 peptide:metal 1 :metal 2 ), $\mathrm{pH} 5.5, \mathrm{~A} B 1-40$ concentration being $10 \mathrm{pmol} / \mu \mathrm{L}$ In order to study the binding of the individual metal ions to peptide at higher $\mathrm{pH}$, triethanolamine was added instead of acetic acid to obtain pH 8.00,9.00, and 9.20, respectively. Besides, the binding of metal ions to $\mathrm{AB1}-40$ was studied at $\mathrm{pH} 7.4$ or 6.6 using $5 \mathrm{mM}$ ammonium acetate as a solvent. All masses were calculated using the charge state ruler tools provided with Bruker Daltonics DataAnalysis software of MS instrument. This software is able to select all of the various charged molecular ions, corresponding to the same peptide or metal-peptide complex.

In order to identify the characteristic signals for some important metal ion-peptide complexes in more complicated spectra we applied two main strategies. First, the spectra of the complexes with low metal ion-peptide ratios were carried out. Next, ESI-mass spectra of higher metal ion-peptide ratio complexes or those at high $\mathrm{pH}$ were recorded. The signals found in the first spectra were identified in the more complicated spectra, using also the charge state ruler.

\subsection{Circular dichroism (CD) spectroscopy}

CD spectra were recorded using a Jasco spectropolarimeter model J-710 (Labor and Datentechnik GmbH, Germany). All measurements were performed in quartz cells with a path length of $0.5 \mathrm{~mm}$. Data were collected at the wavelengths from 180 to $260 \mathrm{~nm}$ in $0.2 \mathrm{~nm}$ increments. Four individual measurements were averaged in order to obtain the reported $\mathrm{CD}$ spectrum. The measurements were carried out at $25.0 \pm 0.2^{\circ} \mathrm{C}$. Calculations of the fractional percentage of secondary structures were carried out using the computer programs SpectraManager (Jasco), CD-Deconvolution and Dicroprot [22].

\subsection{Atomic force microscopy (AFM)}

Images were taken at room temperature $\left(22^{\circ} \mathrm{C}\right)$ on a SPM Solver PRO-M AFM (NT-MTD Co. Zelenograd, Moscow, Russia) using the tapping mode. All images were acquired using a high resolution no contact "Golden" silicon NSG10/Au/50 cantilever with Au conductive coating. The cantilever was $100 \mu \mathrm{m}$ in length, $35 \mu \mathrm{m}$ in width, and with a $2 \mu \mathrm{m}$ thickness and had a typical tip radius of $10 \mathrm{~nm}$. A 
resonant frequency of $254 \mathrm{kHz}$ and a force constant of $11.5 \mathrm{~N} / \mathrm{m}$ were applied. All AFM images were obtained at a resolution of $256 \times 256$ pixels on a scale of $10 \mu \mathrm{m} \times 10 \mu \mathrm{m}$. Image analysis was done with scanning probe microscopy software, WSxM 4.0 Develop 10.0 (Nanotec Electronica S. L.).

\section{Results}

Synthetic $A B 1-40$ peptide showed characteristic peaks at $\mathrm{m} / \mathrm{z}$ $722.3\left([\mathrm{M}+6 \mathrm{H}]^{6+-t}\right.$, the highest peak $)$, and 866.5 for $[\mathrm{AB}+5 \mathrm{H}]^{5+}$. The molecular ions $\left[\mathrm{M}-\mathrm{H}_{2} \mathrm{O}+6 \mathrm{H}\right]^{6+}$ and $\left[\mathrm{M}-\mathrm{H}_{2} \mathrm{O}+5 \mathrm{H}\right]^{5+}$ also appeared in the spectrum and displayed relative intense signals at $\mathrm{m} / \mathrm{z} 719.4$ and 863.0, respectively (Fig. 1,a). In addition, the aspartic acid-lacking Aß31-40, namely y39 fragment, with MW 4211.1 was identified, being more visible in the spectra of metal ion-peptide complexes.

\subsection{Copper binding to $A \beta 1-40$ at $\mathrm{pH} 5.5$}

Our study revealed a significant copper binding to $A \beta 1-40$ peptide at pH 5.5 and a 1:1 Cu:AB molar ratio (Fig. 1,b). The $\mathrm{Cu}-\mathrm{A}(3$ complex appeared in the spectrum at $\mathrm{m} / \mathrm{z} 628.1(7+), 732.5(6+), 878.8(5+)$. and $1098.3(4+)$, respectively. The second copper atom was present in the following copper-peptide ions: $[\mathrm{M}+2 \mathrm{Cu}+3 \mathrm{H}]^{7+}(\mathrm{m} / \mathrm{z}$ 636.8), $[\mathrm{M}+2 \mathrm{Cu}+2 \mathrm{H}]^{6+}(\mathrm{m} / \mathrm{z} 742.9),[\mathrm{M}+2 \mathrm{Cu}+\mathrm{H}]^{5+}(\mathrm{m} / \mathrm{z} 891.0)$, and $[\mathrm{M}+$ $2 \mathrm{Cu}]^{4+}(\mathrm{m} / \mathrm{z}$ 113.5).

No complex between two or more molecules of peptide and copper ions was identified in the mass spectrum at acidic $\mathrm{pH}$.

The relative intensity of $[\mathrm{M}+\mathrm{Cu}+4 \mathrm{H}]^{6+}$ was $83.8 \%$ as compared to that of $[\mathrm{M}+6 \mathrm{H}]^{\mathrm{G}+}$, whereas the corresponding ion $\left[\mathrm{M}-\mathrm{H}_{2} \mathrm{O}+\mathrm{Cu}+\right.$ $4 \mathrm{H}]^{6+}$ was only $27.7 \%$ of the $\left[\mathrm{M}-\mathrm{H}_{2} \mathrm{O}+4 \mathrm{H}\right]^{6+}$ intensity. These data showed that possible conformational changes due to water loss diminished the capacity of the amino terminal area of $A B$ peptide to bind certain heavy metal ions.

\subsection{Zinc binding to $A B 1-40$}

At $\mathrm{pH} 5.5, A \beta 1-40$ molecules may bind up to two zinc ions with different intensities. Whereas the seven charged ions of the peptide did not appear in the mass spectrum, the zinc-A $\beta$ peptide complex showed an intense signal at $\mathrm{m} / \mathrm{z} 628.3$ (Fig. 1c), which was assigned to $[\mathrm{M}+\mathrm{Zn}+5 \mathrm{H}]^{7+}$ ion. $\mathrm{A} \beta-\mathrm{Zn}$ complex was also confirmed by the peaks at $\mathrm{m} / \mathrm{z} 732.8(6+), 879.0(5+;$ a less intensive signal), and 549.9 ( $3.5 \%$ of the intensity of 722.3 peak, $\left.[\mathrm{M}+\mathrm{Zn}+6 \mathrm{H}]^{8+}\right)$.

The $\mathrm{Zn}-\mathrm{A} / 3$ complex with $\mathrm{Zn}: \mathrm{AB}$ molar ratio $2: 1$ appeared in the spectrum at $\mathrm{m} / \mathrm{z} 743.3\left(17.8 \%,[\mathrm{M}+2 \mathrm{Zn}+2 \mathrm{H}]^{6+}\right), 637.8(7.6 \%,[\mathrm{M}+$ $\left.2 \mathrm{Zn}+3 \mathrm{H}]^{7+}\right)$, and $892.2,\left(4.2 \%[\mathrm{M}+2 \mathrm{Zn}+\mathrm{H}]^{5+}\right)$, respectively.

The loss of a molecule of water reduced the zinc binding capacity of A $31-40$ probably due to conformational changes. Nevertheless, a small peak at $m / z 751.9$ was noted, which was assigned to $\left[M-\mathrm{H}_{2} \mathrm{O}+\right.$ $3 \mathrm{Zn}]^{6+}$.

\subsection{Nickel binding to $A \beta 1-40$}

A(31-40 peptide displayed a high affinity toward nickel ions even at low pH (Fig. 1,d). Up to three nickel ions bound to each molecule of $\beta$-amyloid peptide as demonstrated by the peaks at $\mathrm{m} / \mathrm{z} 722.2,731.7$, 741.2 , and 750.6 , which were assigned to $[\mathrm{M}+6 \mathrm{H}]^{6+-},[\mathrm{M}+\mathrm{Ni}+4 \mathrm{H}]^{6+-}$. $[\mathrm{M}+2 \mathrm{Ni}+2 \mathrm{H}]^{6+}$, and $[\mathrm{M}+3 \mathrm{Ni}]^{6+}$, respectively. On the other hand, the signals of five-charged ions at $\mathrm{m} / \mathrm{z} 877.8$ and 888.9 clearly confirmed the formation of $\mathrm{Ni}-\mathrm{AB} 1-40$ complexes in the molar ratios $1: 1$ and 1:2. Low intensity signals, which were assigned to the complex of $A B 1-40$ with four nickel ions, were also found at $\mathrm{m} / \mathrm{z} 912.4(5+), 760.6(6+)$, $652.1(7+), 570.7(8+), 507.2(9+), 380.8(12+)$, and $304.9(15+)$, respectively.

\subsection{Silver and iron binding to $A \beta 1-40$}

Both silver and iron ions displayed different binding patterns as compared to the other investigated metal ions. The intense signal at $\mathrm{m} / \mathrm{z} 740.1$ was assigned to $\mathrm{Ag}-\mathrm{A} \beta 1-40$ complex (Fig. 1,e). Water loss from the $A \beta$ molecule may result in conformational changes with lower metal binding capacity, which was evident from both $A \beta$ complexes with silver and the other metal complexes (Fig. 1,b-e). The other signal for $A g-A B 1-40$ complex at $\mathrm{m} / \mathrm{z} 887.8$ with lower intensity as compared to the $[\mathrm{M}+\mathrm{Ag}+5 \mathrm{H}]^{6+}$ signal was assigned to $[\mathrm{M}+\mathrm{Ag}+$ $4 \mathrm{H}]^{5+}$ (Fig. 1,e).

Iron(III) ion produced both the oligomerization of the peptide and iron-rich high molecular mass complexes. Besides the above mentioned signals, iron ions produced many other $\mathrm{Fe}-\mathrm{A} \beta$ species that were identified with the help of the charge state ruler (Fig. 2). Because the main signals of $\mathrm{Fe}-\mathrm{A}(\mathrm{B}$ complexes hindered the display of other lower signals, we had to investigate a narrower $m / z$ range, close to $m / z 722.3$ $\left(\mathrm{m} / \mathrm{z}\right.$ of $\left.[\mathrm{M}+6 \mathrm{H}]^{6+}\right)$. Here, $5+, 6+$, and $7+$ ions of $A \beta 1-40$ together with the multi-charged ions of multi-ratio Fe-A $\beta 1-40$ complexes, including that of $[\mathrm{M}+3 \mathrm{Fe}-3 \mathrm{H}]^{6+1}$ ion, were found in the spectrum. In fact, a large group of $F e(I I I)-A B 1-40$ complexes was identified with the help of a single ESI ion trap mass spectrum, starting from that of the $A \beta 1-40$ pentamer with only one iron ion, $[5 \mathrm{M}+\mathrm{Fe}+32 \mathrm{H}]^{35+}$, and ending to the complex with nine iron ions bound to one $A B 1-40$ molecule. Although iron binding to peptides will be discussed elsewhere, the presence of high molecular complexes such as that containing four molecules of $A \beta$ and six iron ions should be outlined.

\subsection{Metal-metal interactions during the binding process}

The previous results demonstrated that potential target sites for the evaluation of metal binding need to be carefully analyzed for interfering metal-metal interactions $[19,23-28]$. In this study, decreases of bound silver by $A \beta$, and an increase in bound copper were the most pronounced interactions between the two toxic metals (Fig. 3). Under the same $\mathrm{pH}$ and concentration conditions, the binding pattern of the independent copper and silver ions to $A B 1-40$ was different from that of the equimolecular mixture of the two metal ions. First, $A B 1-40$ bound easily one copper ion to form the $\mathrm{M}+\mathrm{Cu}+$ $4 \mathrm{H}]^{6+}$ complex, which was detected at $\mathrm{m} / \mathrm{z} 732.5$. Only a small part of $A B 1-40$ molecules produced complexes containing two copper ions bound to one $A \beta$ molecule $\left(\mathrm{m} / \mathrm{z} 742.7 ;[\mathrm{M}+2 \mathrm{Cu}+2 \mathrm{H}]^{\mathrm{G}+1}\right)$. Waterlacking $A \beta 1-40$ had a lower affinity towards copper ions than the normal $A \beta 1-40$ (Fig. $3, a ; m / z$ 729.7). Second, both $A \beta 1-40$ and $A \beta 1-$ $40-\mathrm{H}_{2} \mathrm{O}$ molecules proved to have a high affinity toward silver ions (Fig. 3,b), forming mono-silver complexes (m/z 737.3 and 740.1 , respectively). The bi-silver complexes at $\mathrm{m} / \mathrm{z} 757.9$ corresponding to $[\mathrm{M}+2 \mathrm{Ag}+4 \mathrm{H}]^{6+}$ were not considered because of their low intensity.

The picture of copper-silver interaction to $A B 1-40$ was highly complex and had a completely unexpected pattern (Fig. 3,c). In addition to the peaks in the individual spectra of copper and silver, characteristic signals for peptide oligomerization by copper ions $(\mathrm{m} / \mathrm{z} 738.3 ;[2 \mathrm{M}+$ $\left.3 \mathrm{Cu}]^{6+}\right)$ and those for ternary complexes $\left([\mathrm{M}+\mathrm{Ag}+\mathrm{Na}+4 \mathrm{H}]^{6+1}, \mathrm{~m} / \mathrm{z}\right.$ 744.0; $[\mathrm{M}+\mathrm{Cu}+\mathrm{Ag}+3 \mathrm{H}]^{6+1}, \mathrm{~m} / \mathrm{z}$ 749.3) were found (Table 1). Apparently, copper diminished the signal of $[\mathrm{M}+\mathrm{Ag}+5 \mathrm{H}]^{6+}$ ion at $\mathrm{m} / \mathrm{z} 740.1$, but stimulated the formation of silver complexes with water-loss $A B 1$ 40 from $\mathrm{m} / \mathrm{z}$ 737.3. For example, $\left[\mathrm{M}-\mathrm{H}_{2} \mathrm{O}+\mathrm{Ag}+5 \mathrm{H}\right]^{6+1}$ and $\left[\mathrm{M}-\mathrm{H}_{2} \mathrm{O}+\right.$ $2 \mathrm{Ag}+4 \mathrm{H}]^{6+}$ displayed intense signals at $\mathrm{m} / \mathrm{z} 737.3$ and 755.5 , respectively. Silver ions potentated the binding capacity of copper ions to $A \beta$, including $A B 1-40$ without one molecule of water. Thus, the intense signals at $\mathrm{m} / \mathrm{z} 763.6$ and 761.7 were assigned to $[\mathrm{M}+4 \mathrm{Cu}-2 \mathrm{H}]^{6+1}$ and $\left[\mathrm{M}-\mathrm{H}_{2} \mathrm{O}+\right.$ $4 \mathrm{Cu}-2 \mathrm{H}]^{6+}$. We hypothesized that silver binding to $\mathrm{A} \beta 31-40$ peptide and especially to $A B 1-40-\mathrm{H}_{2} \mathrm{O}$ one might result in the formation of silver-AB complexes in such a conformation that would enable them to react easily with copper ions. In this case, silver ions probably catalyze copper binding 
to $A B$ peptides via a reaction mechanism based on conformational changes and replacing peptide-bound silver ions by copper ions.

Within these experiments, the charge state ruler proved to be quite effective in identifying the peaks in the complicated spectra of noncovalent complexes of peptides.

\subsection{Metal ion binding to $A \beta 1-40$ at basic $p H$}

Relatively small pH changes may affect the metal ion-binding capacity of the peptides and proteins. On increasing the $\mathrm{pH}$ due to the use of triethanolamine, the solution containing $A B$ peptide may provide rather complicated mass spectra in the presence of individual metal ions. The high pH ESI-MS spectra of proteins or even simple peptides are far too complex for interpretation as most of the signals overlap heavily. Under the same conditions, the spectra of metal ion-peptide adducts become rather complicated but not impossible to be deciphered. By the introduction of additional methodological strategies, such as the comparison of complicated spectra with those obtained at low pH and lower metal ion concentration, as well as the use of the charge state ruler the

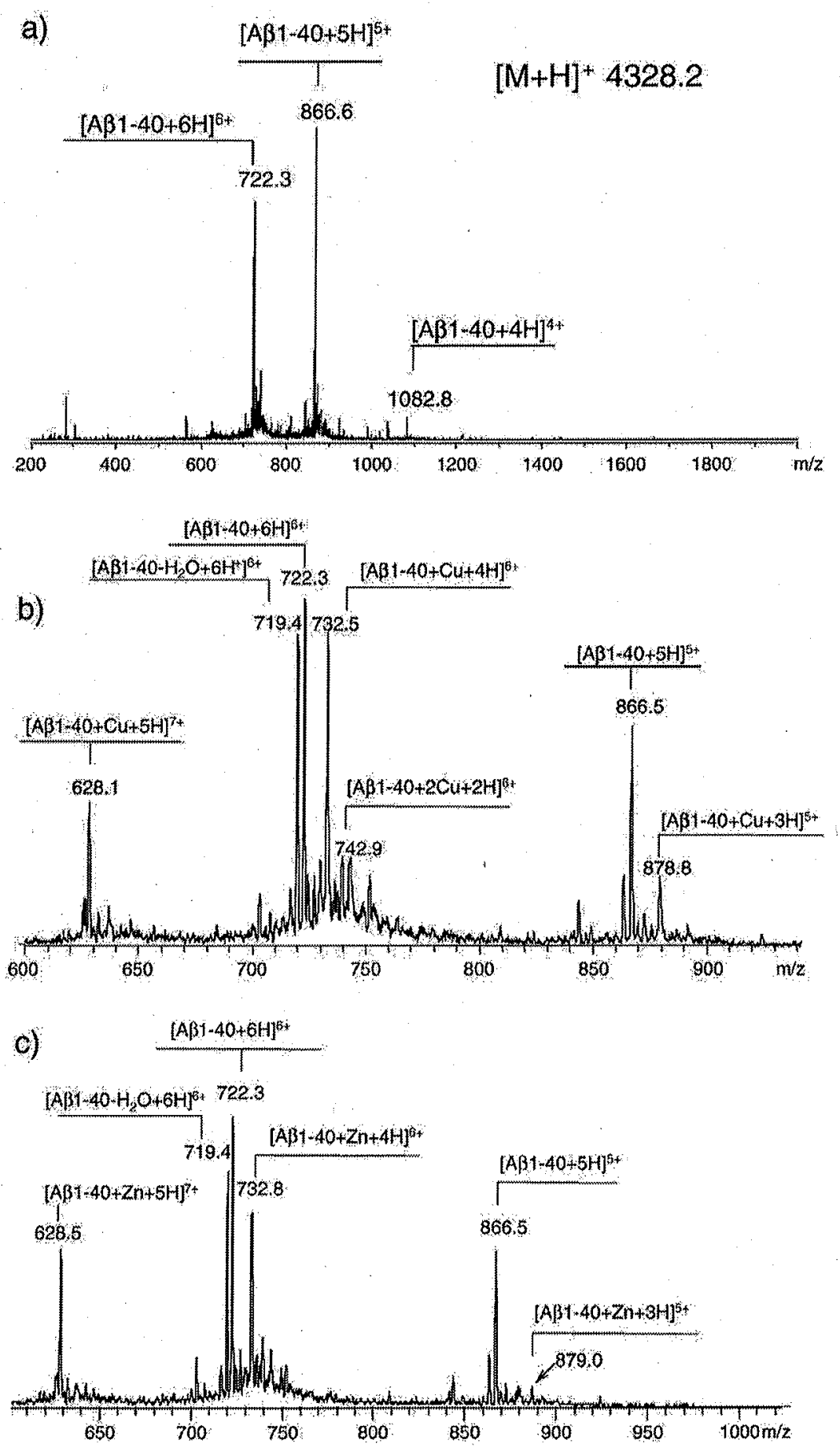

Fig. 1. ESI ion trap mass spectrum of Aß31-40 (a) as well as its complexes with copper(II) [49] (b), zinc(II) (c), nickel(II) (d), and silver(I) (e) ions at pH 5.5 . 


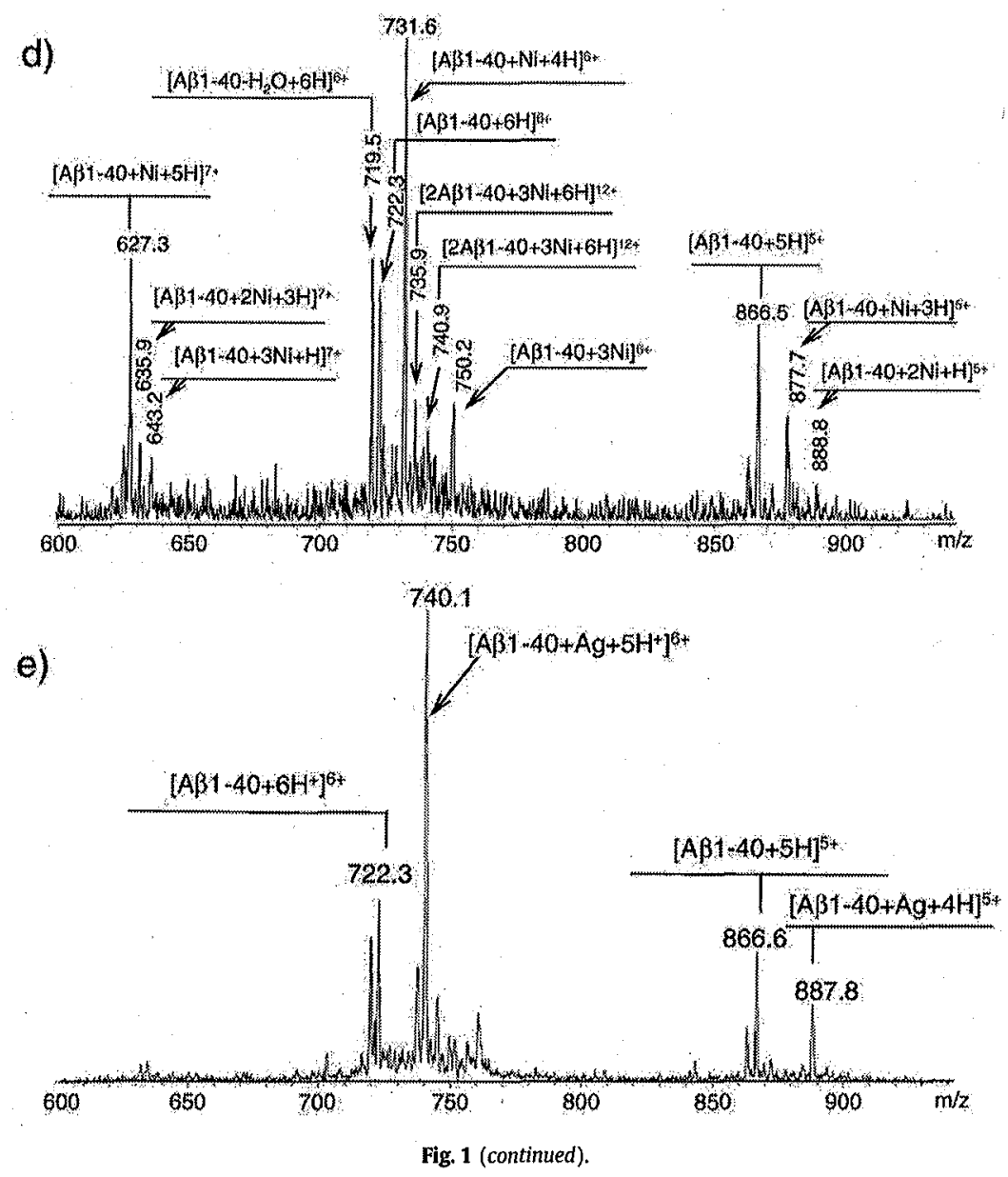

complex spectra were much simplified and some extra information was obtained.

\subsubsection{Copper binding to amyloid- $\beta$ peptide at $\mathrm{pH} 8.0$}

A slight increase in $\mathrm{pH}$ dramatically stimulated copper ion binding to $A \beta 1-40$ (Fig. 4). Thus, $A \beta 1-40$ peptide bound only one copper ion at
pH 6.6 (Fig. 4,a), whereas species with one, two and even three copper ions were determined at pH 8.0 (Fig. 4,b).

\subsubsection{Zinc binding}

Although the mass spectrum of $A B$ peptide treated with 10:1 molar ratio zinc ions seems to be very simple, when enlarged each peak of

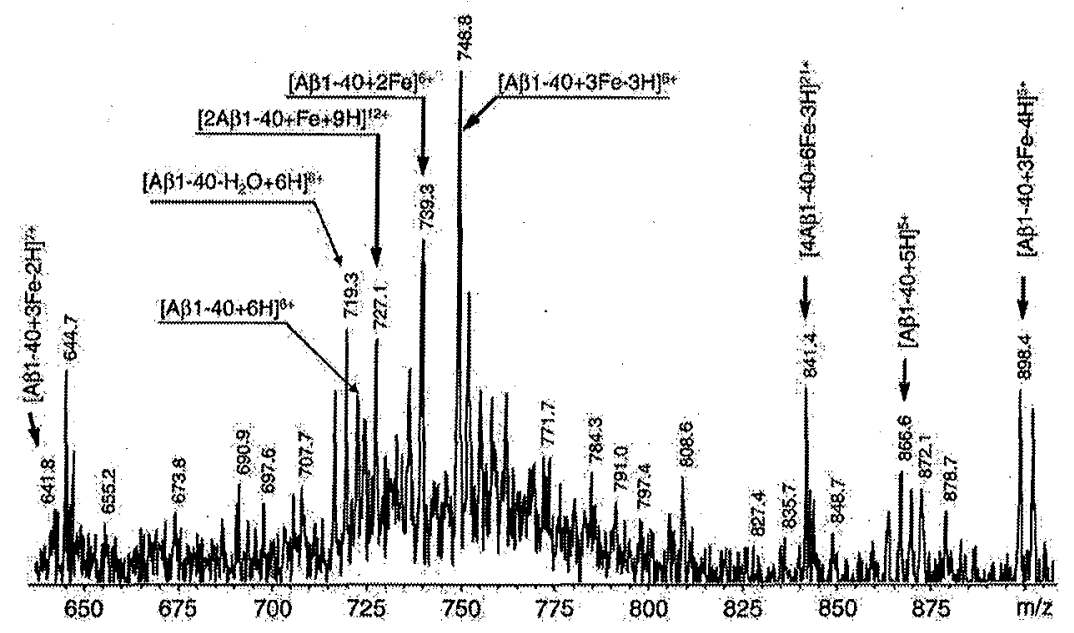

Fig. 2. Species of iron(III) ion-AB1 -40 complex at $\mathrm{pH} 5.5$, as displayed in a truncated ESI ion trap mass spectrum, free $A \beta 1-40$ peptide ions $(6+, \mathrm{m} / \mathrm{z} 722.3 ; 5+, \mathrm{m} / \mathrm{z} 866.6) \mathrm{may}$ coexist with complexes containing three iron ions $(\mathrm{m} / \mathrm{z} 641.8 ; 748.8 ; 898.4)$, two $(\mathrm{m} / \mathrm{z} 739.3)$ or other various ones, Oligomerization is also possible $(\mathrm{m} / \mathrm{z}$ 727.1). 

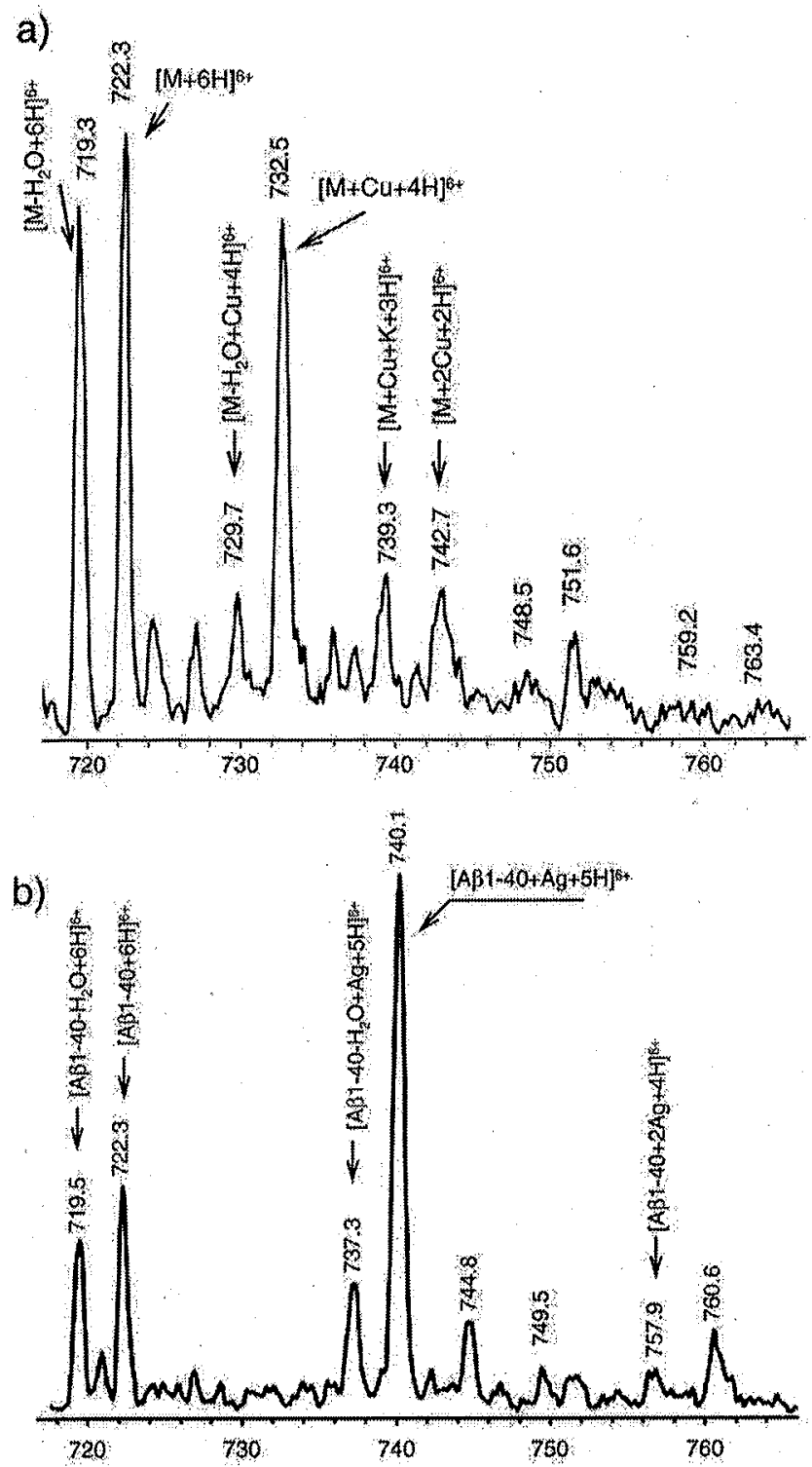

c)

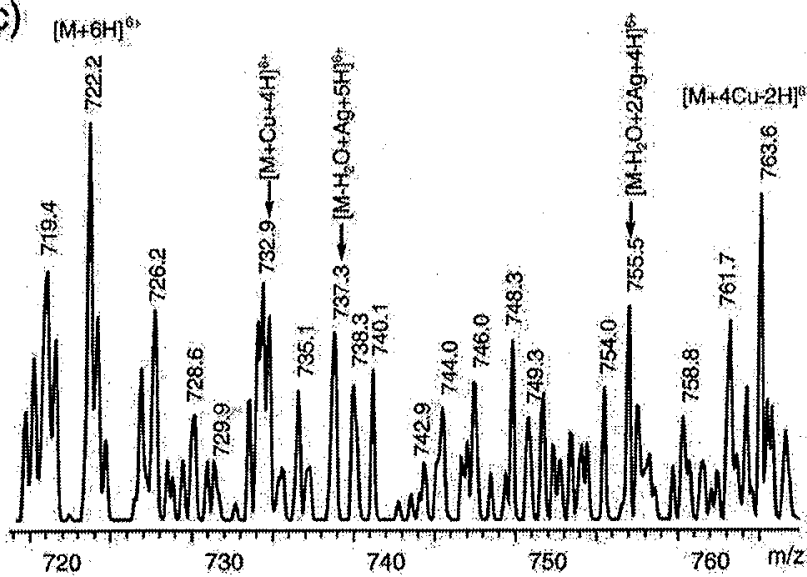

Fig. 3. Binding competition or synergism between copper ions and silver ones to $A \beta 1$ 40 sites at $\mathrm{pH}$ 5.5: a) copper binding to $A(3 ;$ b) silver binding to $A(B ; c)$ copper and silver binding to $A \beta$. this one becomes a complex group of signals belonging to various $\mathrm{Zn}$ (II)-A $\beta$ species. The characteristic signals of $A \beta 1-40$ practically disappeared and specific signals of $A B$ molecules complexes with from two to ten zinc ions appeared in the mass spectrum (Fig. 5,a). For example, the major peak at $\mathrm{m} / \mathrm{z} 638.0$ was assigned to $[\mathrm{M}+2 \mathrm{Zn}+5 \mathrm{H}]^{7 \cdot 4}$, being accompanied by the other signals of this molecular complex at $\mathrm{m} / \mathrm{z} 203.9$ $(22+), 248.8(18+), 344.2(13+)$ and $447.0(10+)$. Searching for metalricher complexes of $A B$ peptide, we found a well expressed complex of one molecule of $A \beta$ with six ions of zinc; its major peak was displayed at $\mathrm{m} / \mathrm{z} 337.1(14+)$, and the others at $\mathrm{m} / \mathrm{z} 214.8(22+), 363.0(13+), 428.9$ $(11+), 523.8(9+)$, and $941.8(7+)$, respectively. In addition, the signal at $\mathrm{m} / \mathrm{z} 355.0(14+)$ was assigned to $[\mathrm{M}+10 \mathrm{Zn}-6 \mathrm{H}]^{14+}$. Whereas the peak at $m / z 638.0$ was assigned to one $A(31-40$ molecule bound to two zinc ions, the signal at $\mathrm{m} / z 637.0(8+)$ revealed the presence of $A \beta$ peptide bound to 12 zinc ions. The existence of this complex was also confirmed by the most intense signal in the group around $\mathrm{m} / \mathrm{z} 850.0(\mathrm{~m} / \mathrm{z} 848.9$, $\left.[\mathrm{M}+12 \mathrm{Zn}-18 \mathrm{H}]^{6+}\right)$ as well as by the peaks at $\mathrm{m} / \mathrm{z} 424.9(12+), 636.9$ $(8+)$, or $(727.8(7+)$. Although the $\mathrm{m} / \mathrm{z} 203.9$ signal was associated with $A \beta 1-40+2 \mathrm{Zn}$ complex $(22+)$, it also belongs to $\left[\mathrm{M}-\mathrm{H}_{2} \mathrm{O}+12 \mathrm{Zn}+\right.$ $\mathrm{H}]^{25+4}$ ion, and therefore this signal was found highly intensive, being the sum of two independent signals.

The most intense signal at $\mathrm{m} / \mathrm{z} 211.9$ was assigned to $[\mathrm{M}+5 \mathrm{Zn}+$ $12 \mathrm{H}]^{22+}$, so that, of so many peaks in the spectrum, the majority of them belongs to monomolecular $A \beta$ complexes with more than one ion of zinc.

\subsubsection{Nickel binding}

The characteristic signals for $A \beta$ peptide practically disappeared and various groups of new signals revealed a complex pattern of nickel binding to peptides (Fig, 5,b). In aqueous solutions of nickel salts and A $31-40$ peptide found in a molar ratio of 10:1, either single molecules of $A \beta$ bound one to more nickel ions or $A \beta$ oligomers bound nickel in various proportions. First, we identified the simplest complex of $A B 1-40$ with nickel, $[\mathrm{M}+\mathrm{Ni}+4 \mathrm{H}]^{\mathrm{G}+}$, at $\mathrm{m} / \mathrm{z} 732.0$ and $209.9(21+)$ or $232.0(19+)$. Nevertheless, one molecule of $A \beta$ proved to bind more than five ions of nickel. For example, the peak at $\mathrm{m} / \mathrm{z} 203.9$ could be assigned to six nickel ions bound to $A B 1-40$. However, nickel ions seem to be able to form oligomers when bound to peptides; the highest peak in the spectrum, $\mathrm{m} / \mathrm{z}$ 355.1, was assigned to a metal-peptide complex containing three molecules of $A B 1-40$ and two nickel ions. The existence of $[3 M+$ $2 \mathrm{Ni}$ ] complex was also confirmed by the signals at $\mathrm{m} / \mathrm{z} 655.9(20+)$, $546.9(24+)$ and others. Even a single ion of nickel may induce oligomerization of $A \beta$ peptide. An $A \beta 1-40$ trimer bound to a nickel ion was identified at $\mathrm{m} / \mathrm{z} 207.9,221.9,225.8,622.0$, etc. On increasing the $\mathrm{pH}$ and metal ion:peptide ratio, the spectra pattern became complicated dramatically. To avoid the assignment of some $\mathrm{m} / \mathrm{z}$ values to false species, we referred only to the most evident complexes of $A \beta$ with the investigated metal ions as revealed by the significant signals in the spectra. In addition, we increased stepwise both $\mathrm{pH}$ and metal ion concentration and followed the appearance of the new peaks that prove the formation of new species.

\subsubsection{Silver binding}

Generally, silver ions bound to individual molecules of $A B 1-40$, without forming oligomeric species. $A B 1-40$ peptide without one

Table 1

The main molecular ions identified in Fig. 3,c.

\begin{tabular}{|c|c|c|c|}
\hline m/2 & Wolecular ron & $10 / 2$ & Molecular Ion \\
\hline $\begin{array}{r}194 \\
7262 \\
286 \\
799 \\
329 \\
778 \\
38\end{array}$ & 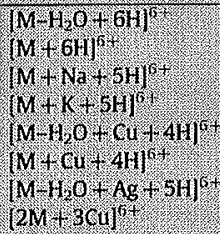 & $\begin{array}{l}7404 \\
7429 \\
740 \\
79.3 \\
7540 \\
755.5 \\
7617 \\
763.6\end{array}$ & 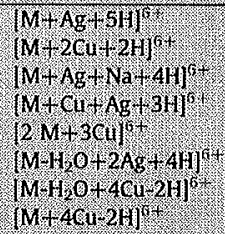 \\
\hline
\end{tabular}




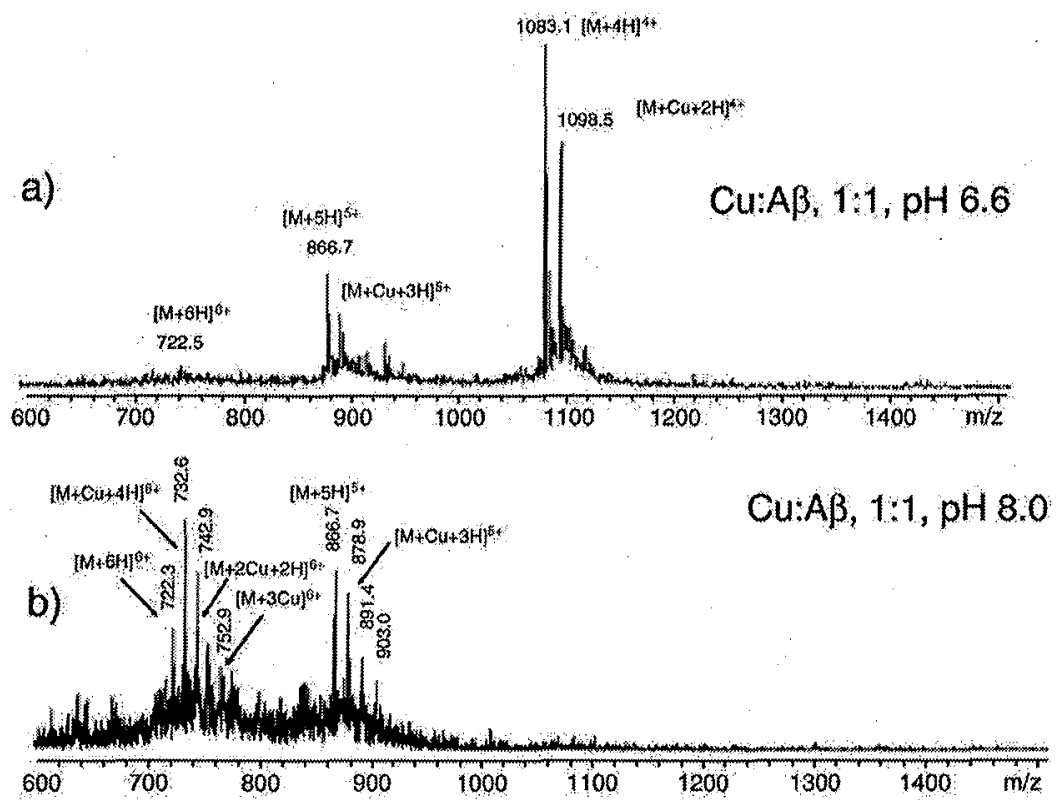

Fig. 4. Effect of $\mathrm{pH}$ on copper binding to $A(31-40: a)$ ESI ion trap mass spectrum of copper ion-A $31-40$ peptide complex at pH 6.6, and b) MS spectrum of the complexes formed at pH 8.0. The molar ratio of $C U(\mathrm{II}): A \beta$ was $1: 1$.

molecule of water proved to bind easily eight silver ions to form an $A \beta$ complex that displayed specific signals in the mass spectrum at $\mathrm{m} / \mathrm{z}$ $1034.5(5+)$, as well as at $\mathrm{m} / \mathrm{z} 862.4(6+), 739.2(7+), 575.2(9+)$, $370.1(14+), 324.1(16+), 305.1(17+), 288.1(18+), 273.1(19+)$, $247.0(21+)$, and $236.0(22+)$, respectively. Another peak at $\mathrm{m} / \mathrm{z}$ 1035.4 was assigned to $[\mathrm{M}+8 \mathrm{Ag}-3 \mathrm{H}]^{5+}$, which was less intensive than that of $\left[\mathrm{M}-\mathrm{H}_{2} \mathrm{O}+8 \mathrm{Ag}-3 \mathrm{H}\right]^{5++}$. This complex of $\mathrm{AB} 1-40$ with eight silver ions was also supported by characteristic signals at $\mathrm{m} / \mathrm{z}$ $863.2(6+), 518.2(10+), 471.1(11+), 432.2(12+), 226.0(23+)$, and $208.0(25+)$, respectively.

The peak at $\mathrm{m} / \mathrm{z} 216.0(23+)$ also appeared at $\mathrm{m} / \mathrm{z} 990.4$ associated with $\left[\mathrm{M}-\mathrm{H}_{2} \mathrm{O}+6 \mathrm{Ag}-\mathrm{H}\right]^{5+}$ complex, and consequently, it was assigned to $A B 1-40$ complex with six silver ions, being present at $\mathrm{m} / \mathrm{z} 413.1(12+)$, and $\mathrm{m} / \mathrm{z} 226.0(22+)$.

Looking for metal-richer complexes of $A B 1-40$, we found a signal at $\mathrm{m} / \mathrm{z} 689.3$, which could be assigned to $[\mathrm{M}+11 \mathrm{Ag}-3 \mathrm{H}]^{8+}$. However, first we calculated the molecular weight of this complex and looked for its five charged ion $(\mathrm{m} / \mathrm{z} 1102.5)$. Following this procedure, we identified the other peaks of $A \beta 1-40$ molecules, each of them containing eleven silver ions, such as $\mathrm{m} / \mathrm{z} 788.3(7+), 368.0(15+)$, $345.1(16+), 325.1(17+), 307.1(18+)$, and $263.1(21+)$, respectively. $\mathrm{AB1}-40$ proved to bind also $12 \mathrm{Ag}$ ions to each molecule as revealed by the relatively less intense signals at $\mathrm{m} / \mathrm{z} 1124.4(5+), 937.3(6+)$, $703.3(8+), 625.2(9+), 469.2(12+), 433.2(13+), 402.1(14+), 352.1$ $(16+), 313.1(18+), 235.0(24+), 217.0(26+)$, and $209.0(27+)$.

Finally, the highest peak in the spectrum at $\mathrm{m} / \mathrm{z} 651.2$ was assigned to $[\mathrm{M}+2 \mathrm{Ag}+5 \mathrm{H}]^{7+}$. Hence, treating $A \beta 1-40$ molecules with silver ions in the 1:10 molar ratio, numerous species of silver-peptide complex were found, whereas $A \beta$ adduct with eight silver ions was prevalent. To explain the formation of such a large number of silver$A B$ complexes, we took into consideration the participation of both histidine residues and free amino group as well as carboxylate ones in the binding process.

\subsection{Nickel-silver competition for $A \beta 1-40$ binding sites at basic $p H$}

Treating A $1-40$ in the presence of triethanolamine with a solution containing both silver and nickel ions, a competition among these ions was observed (Fig. 6). Apparently, the spectrum of the silver-nickel-
A $1-40$ peptide system became simplified as compared to those of both silver $-A \beta$ and nickel- $A \beta$ complexes. Indeed, the main signals in this spectrum were only found at $355.0(100 \%), 203.9(77.8 \%), 205.9$ (72.2\%), 411.0 (40.4\%), 357.0 (39.1\%), 413.0 (33.0\%), 337.1 (21.7\%), $618.0(18.9 \%)$, and $653.9(10.9 \%)$, respectively. However, contrary to the current spectra of peptides or metal ion-peptide complexes at neutral $\mathrm{pH}$, each group of signals in a given area of the spectrum of metal ion-peptide complexes could not be assigned to an isotopic distribution but to many individual complexes. For example, the major signal at $\mathrm{m} / \mathrm{z}$ 355.0 consists of a group of two intense peaks and three lower ones, ranging from $\mathrm{m} / \mathrm{z} 355.0$ to $\mathrm{m} / \mathrm{z} 359.0$. The peak at $\mathrm{m} / \mathrm{z} 355.0$ was assigned to $[\mathrm{M}+6 \mathrm{Ag}+8 \mathrm{H}]^{14+\mathrm{t}}$ ion, that at $\mathrm{m} / \mathrm{z} 356.0$ to $[\mathrm{M}+11 \mathrm{Ag}+$ $3 \mathrm{Ni}-\mathrm{H}]^{16+}$, whereas the signal at $\mathrm{m} / \mathrm{z} 357.0$ (calcd. $\mathrm{m} / \mathrm{z} 357.2$ ) was assigned to $[\mathrm{M}+8 \mathrm{Ag}+3 \mathrm{Ni}+\mathrm{H}]^{15+}$, and $\mathrm{m} / \mathrm{z} 358$ could be assigned to $[\mathrm{M}+3 \mathrm{Ag}+10 \mathrm{H}]^{13+-}$, although they are differently charged and contain various ratios between the metal ions.

Therefore, we searched first for the signals' characteristic to 1:1 molar ratio $\mathrm{Ni}-\mathrm{AB}$ complexes. Indeed, one can find low signals, at the detection limit, for one nickel ion bound to a single molecule of $A B 1$ 40 at $\mathrm{m} / \mathrm{z} 731.9(6+), 488.3(9+), 338.3(13+), 231.9(19+)$, and $209.9(21+)$ only. Nevertheless, trace signals at $\mathrm{m} / \mathrm{z} 741.2(6+), 635.5$ $(7+), 371.0(12+)$, and $247.7(18+)$ could be attributed to $A \beta 1-40$ complex with two nickel ions. In addition, the existence of $3 \mathrm{Ni}: \mathrm{AB} 1-40$ molar ratio complex was demonstrated by the signals at $\mathrm{m} / \mathrm{z} 750.8$ $(6+), 563.3(8+), 451.0(10+), 410.0(11+)$, and $250.9(18+)$. We also found $4 \mathrm{Ni}: A B 140$ complex at $\mathrm{m} / \mathrm{z} 651.9(7+), 506.9(9+), 414.9$ $(11+)$, and $207.9(22+)$ as well as species containing five nickel ions in a molecule at $771.1(6+), 660.9(7+), 385.9(12+)$, and $201.9(23+)$, respectively.

No other signals for nickel ions bound to $A \beta$ were found except those characteristic to $6 \mathrm{Ni}: \mathrm{A} \beta 31-40$ molar ratio: $780.9(6+), 586.0$ $(8+), 361.0(13+)$, and $223.9(21+)$. We also searched for signals according to their calculation using masses for the expected complexes. Thus, we found characteristic signals for $A g: A \beta, 2 A g: A B$, or for $\mathrm{Ag}: \mathrm{Ni}: \mathrm{AB}, 2 \mathrm{Ag}: \mathrm{Ni}: \mathrm{AB}$, etc.

Nevertheless, each signal in a small range of $m / z$ values consists of many signals, which can be assigned to different silver-A $A$ complexes, or silver-nickel-AB ones. We found a complex with $M W$ 4919.4 composed of one molecule of $A B 1-40$, five silver ions and 

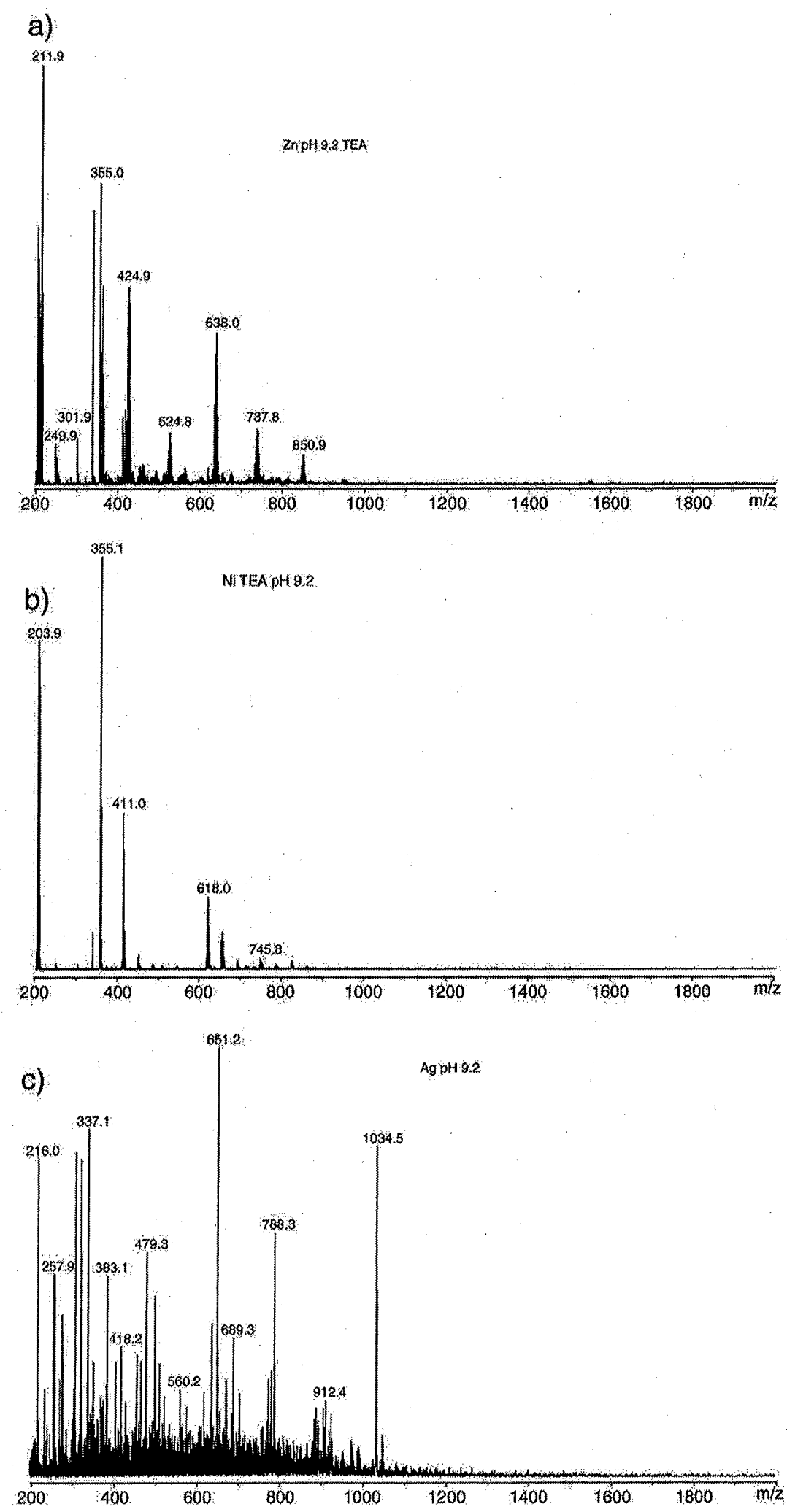

Fig. 5. Metal ion binding to $A \beta$ peptide at pH 9.2: a) ESI ion trap mass spectrum of Ni(II)-AB1-40 peptide complexes; b) $\mathrm{Zn}(\mathrm{II})$ binding to $\mathrm{A} \beta$ at pH 9.2; $\mathrm{Ag}(\mathrm{I})-\mathrm{A} \beta 1-40 \mathrm{Complexe}$ as revealed by MS.

one nickel ion. Its characteristic signals were also found at $\mathrm{m} / \mathrm{z}$ $820.9(6+), 616.0(8+), 448.5(11+), 411.0(12+)$, and $205.9(24+)$, respectively.
The main signal in the area from $\mathrm{m} / \mathrm{z} 201.9$ to 209.9 was that at $\mathrm{m} / \mathrm{z}$ 203.9 , which was assigned to $[\mathrm{M}+11 \mathrm{Ag}+3 \mathrm{Ni}+11 \mathrm{H}]^{28+}$, corresponding to a silver-nickel-A $31-40$ complex with the molecular weight of 


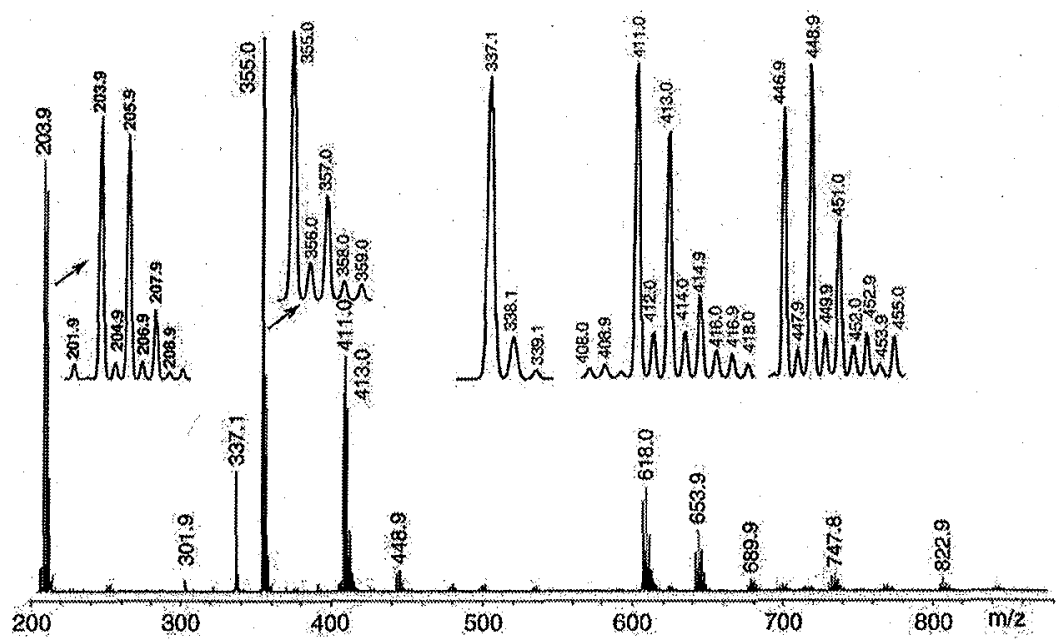

Fig. 6. Competition and synergism between silver and nickel ions within the process of metal ion binding to $A ß 31-40$ peptide at pH 9.2 .

5678.0 (calcd. 5678.6). Its existence was also supported by the other peaks at $\mathrm{m} / \mathrm{z} 710.9(8+), 632.0(9+), 356.0(16+)$, and $247.9(23+)$, respectively. We clearly stated that generally high molecular mass complexes give signals at lower $\mathrm{m} / \mathrm{z}$ values due to their highly charged ions, whereas the low molecular peptides and metal ion-peptide complexes at higher ones.

\subsection{Circular dichroism investigation}

The influence of metal ions on the secondary structure of the $A B 1$ 40 peptide was followed by $\mathrm{CD}$ spectroscopy. Metal ion complexation has previously been shown to be a strong trigger for a secondary structure switch from an a-helix to a $\beta$-sheet [24]. The CD spectra of A $1-40$ peptide $(180 \mathrm{mM})$ in aqueous solutions or in the presence of copper ions, sodium dodecylsulfate and nickel ions at two $\mathrm{pH}$ values are shown in Fig. 7. The CD spectrum of the peptide showed a low degree of ordering $(49.1 \%$ unordered forms and $34.3 \%$ - 3 -sheet conformers), which was not drastically modified by the addition of copper ions. However, a slight increase in the $\mathrm{pH}$ value enhanced the

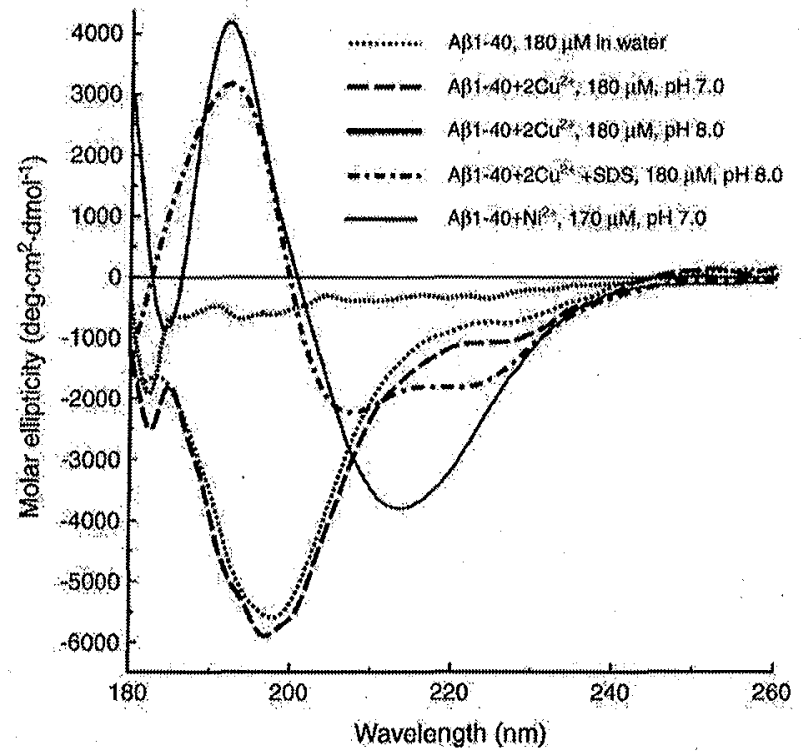

Fig. 7. $C D$ spectra of $A B 1-40$ peptide and of its complexes with copper and nickel ions at pH 7 and 8 and in the presence of sodium dodecyl sulfate (SDS; 1:1 molar ratio). proportion of $\beta$-sheet conformers (up to $40.2 \%$ ). In the presence of SDS, the conformational equilibrium changed from unordered and $\beta$-turn structures to $\beta$-sheet (46\%) and a-helix conformers (Table 2 , Fig. 7). Some other measurements showed that SDS produces similar conformational equilibriums of $A B 1-40$ species that are independent on the $\mathrm{pH}$ values and copper ion concentrations. SDS induced a complete abolition of $\beta$-turn conformers and an increase in the population of $\beta$-sheet conformers (Table 2 ). To explain the atomization of $A B$ aggregates by SDS, even if it produces an increasing in $\beta$-sheet proportion of $A \beta 1-40$ molecules, we considered the hydrophobic interactions between SDS molecules and the hydrophobic amino acid residues of $A \beta 1-40$ molecule, which may induce a shift toward $\alpha$ helical conformers which behave different from fibrillogen $\beta$-sheet ones.

Nickel ions changed dramatically the secondary structure of $A(B 1$ 40 from a large proportion of random coil (49.1\%) to one of $\alpha$-helix conformers (25.3\%). In addition, nickel induced a slow decrease in the population of $\beta$-turn conformers, and a slight increase in that of $\beta$-sheet species (38.5\%). These findings are concordant with the MS measurements, which showed the formation of various nickel-AB140 complexes containing variable molar ratios between $A \beta$ and nickel.

By addition of equimolecular amounts of iron ions, the conformational equilibrium was almost unchanged $(43.7 \%$ unordered conformers and $37.5 \% \beta$-sheet ones). Iron induced a very slow increase in the population of beta conformers, that are related to $A \beta$ toxicity and Alzheimer's pathogenesis. In contrast to copper ions, which increase the proportion of $\beta$-sheet conformers, or nickel ions, which induce the formation of $\beta$-turn species, $\mathrm{Fe}(\mathrm{III})$ had little effect on the conformational equilibrium. However, hydrophobic environments, such as that generated by SDS, increased $\alpha$-helical proportion, which is supposed to reduce $\beta$-sheet toxicity.

Table 2

Conformational changes of $\beta$-amyloid peptide $(A B 1-40$ or $A \beta)$ in the presence of copper

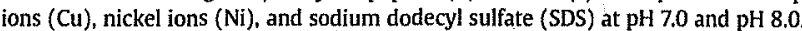

\begin{tabular}{|c|c|c|c|c|c|}
\hline Eonformation ( $(8)$ & $A B 140$ & As/cror & AB/en/pH 8 & AB/Gorsos/pH & ASTNYPH? \\
\hline 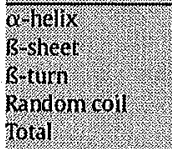 & $\begin{array}{c}60 \\
34 \\
166 \\
497 \\
1000\end{array}$ & $\begin{array}{l}60 \\
34 \\
170 \\
482 \\
1000\end{array}$ & $\begin{array}{c}00 \\
40.2 \\
16.6 \\
43.2 \\
1000\end{array}$ & $\begin{array}{l}228 \\
460 \\
00 \\
372 \\
000\end{array}$ & $\begin{array}{l}253 \\
385 \\
9 \\
97 \\
772 \\
1000\end{array}$ \\
\hline
\end{tabular}



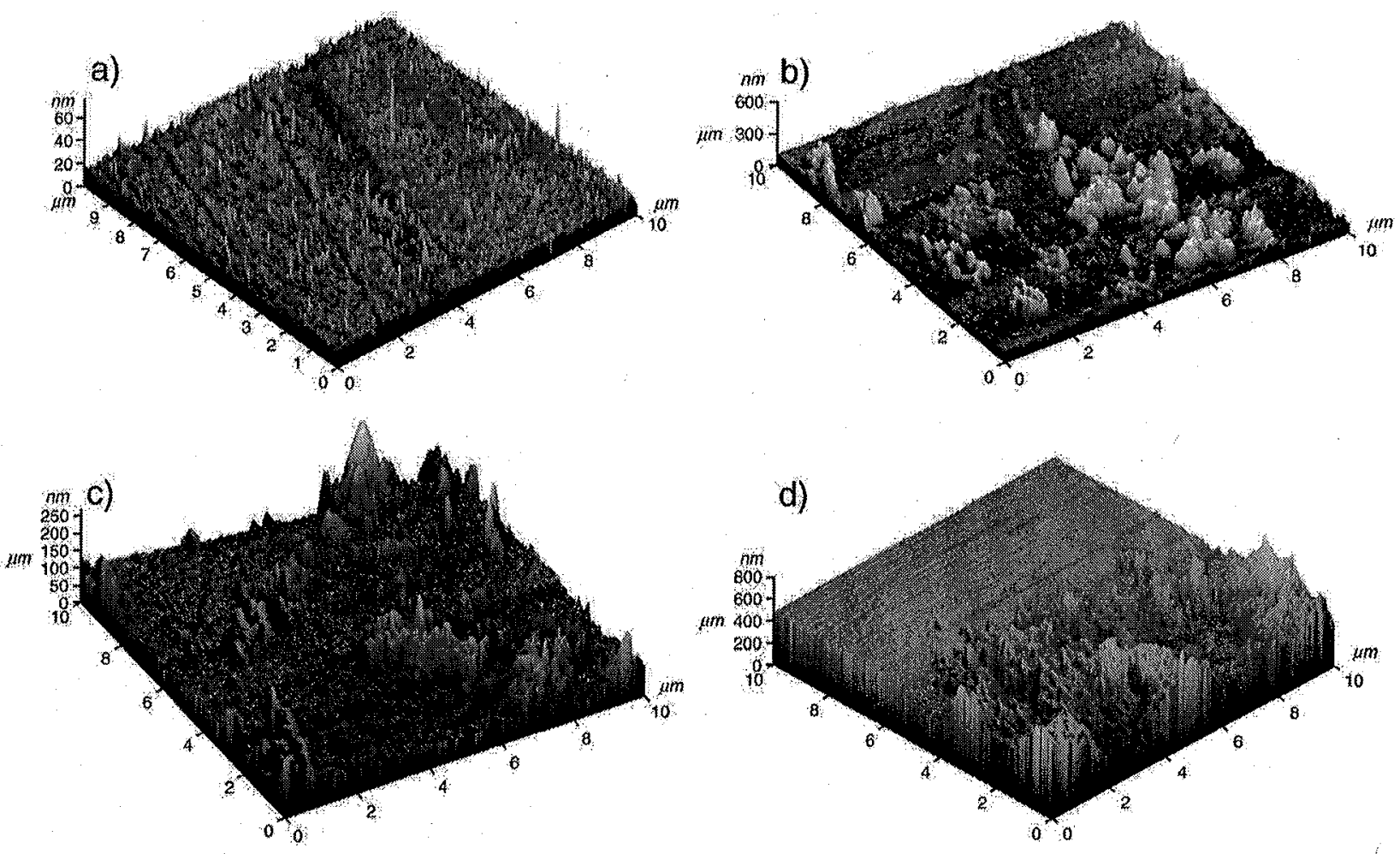

Fig. 8. AFM images $(10 \mu \mathrm{m} \times 10 \mu \mathrm{m})$ of $A B 1-40$ and its $1: 10$ molar ratio adducts: a) $A(B 1-40 ;$ b) $A(31-40+C u 2+; c) A B 1-40+S D S ; d) A B 1-40+S D S+A g+$.

\subsection{Atomic force microscopy investigation}

The self-assembled nanostructures of peptides in aqueous solution were significantly influenced by the presence of metal ions (Fig. 8). Fresh solution of $A B 1-40$ formed a smooth film on the glass plate of the microscope. Copper ion binding to $A B 1-40$ peptide plays an important role in the formation of nanostructures as shown in Fig. 8,b. Copper ions thus generated a rough surface containing numerous big structures as high as $200 \mathrm{~nm}$. It is also clear from this image that copper ions are not able to induce large nanostructures, but small hills, However, the strong contrast between the AFM images recorded before and after copper treatment confirmed a morphological change in the surface packing of the peptide shell. Although SDS do not form non-covalent complexes with $A \beta 1-40$, the high roughness of the surface in Fig. 8,c showed an evident interaction of the two molecules, which results in the formation of supramolecular structures. On treating copper-A $\beta 1-40$ complex with SDS, similar nanostructures are created from these adducts. Similarly, silver-A $\beta 1-40$ film differed dramatically from that of $A \beta 1-40$ one, as well as that of the solution containing silver ions, $A \beta 1-40$ molecules and SDS (10:1:10 molar ratio; Fig. $8, d$ ).

\section{Discussion}

The stoichiometry and binding mode of $A \beta 1-40$ peptide showed a great variety depending on the metal ion to ligand ratio, and $\mathrm{pH}$. These results are concordant with those obtained previously on working with individual metal ions [29-32]. Although blood and internal biochemical environment is characterized by a pH close to 7.39 (7.35-7.45), most fluids inside the body as well as body tissues function at different $\mathrm{pH}$ ranges $[33,34]$. Under various physiological conditions, acutely dissociated neurons were also found to have a wide range of pHi values (6.3-7.7) $[35,36]$. During near-complete rat forebrain ischemia, cerebral intracellular $\mathrm{pH}$ decreased from 7.01 to 6.17 [37]. This was the incentive to investigate the interaction of metals with peptides within a large $\mathrm{pH}$ range. The coordination of metal ions to $A B$ is the same in both aqueous solution and lipid environments, with $\mathrm{His}^{6}, \mathrm{His}^{13}$, and $\mathrm{His}^{14}$ all involved [19]. However, the peptide backbone becomes more important in metal ion-binding process on increasing $\mathrm{pH}$. Nickel ions bind strongly to $\mathrm{A} \beta 1$ 40 even in acidic solutions. Nevertheless, silver ions enhance copper binding to $A B$ in acidic solutions, whereas they compete with nickel ions at higher $\mathrm{pH}$.

The generation of the $A \beta$ toxic species is modulated by the $\mathrm{Cu}^{2+}$ concentration and the ability to form an intermolecular His bridge as demonstrated by EPR spectroscopy [29]. Several spectroscopic studies have indicated that the copper-binding site of $A B$ consists of the three histidine residues His6, His 13 and His14 and an as yet undefined fourth ligand; proposed ligands include Tyr10 [19,38-40], the N-terminal nitrogen $[30]$ or an as yet unidentified carboxylate side chain $[31,32]$.

Our study revealed a high affinity of $A \beta$ toward iron(III) ions, with which $A \beta$ forms both iron-bound oligomers and high molecular weight polymeric species. They might have a high patho-physiological significance because $\mathrm{pH}$ and reduction-oxidation balance of certain cells may alter alongside many pathological processes.

Depending on the $\mathrm{pH}$ values, zinc ions may bind to $A \beta$ peptide in various proportions as our investigation revealed. Although protein chelation of zinc is typically mediated by histidines, cysteines and carboxylates at low $\mathrm{pH}$ [41], amino groups may play an important role under slight alkaline conditions.

Further investigation should be done to clarify the effect of metal ions on the conformational changes of $A \beta$ as well as their interference with the other metal ions within the binding process. $A B(1-16)$ was previously shown to bind up to three cations upon increasing the $\mathrm{Zn}^{2+}$ concentration [2]. Under CID, zinc binding induces specific cleavages after the three histidines of the $A \beta(1-16)$ sequence $\left(H^{6}, H^{13}\right.$ and $\left.H^{14}\right)$, showing their simultaneous implication in the $\mathrm{Zn}^{2+}$ coordination sphere [2]. In addition, Glu11 residue has been identified as providing the carboxylate side chain when $\mathrm{Zn}^{2+}$ is bound to $A B 1-16$ [42].

Circular dichroism spectroscopy and electron microscopy were used as well to monitor the effects of metal ions on the peptide $\beta$-sheet 
conformation and fibril aggregation. These observations indicated a specific zinc binding site within $A \beta$ that involves these central histidine residues. Complementary studies with $\mathrm{Cd}^{2+}$ ions cause perturbations to ${ }^{1} H$ NMR spectra of $A B(1-40)$ that are strikingly similar to that observed for $\mathrm{Zn}^{2+1}[18]$. The binding of divalent metals like $\mathrm{Zn}^{\mathrm{II}}, \mathrm{Cd}^{\mathrm{fl}}$ and $\mathrm{Co}^{\mathrm{In}}$ to a synthetic peptide, APP ${ }^{170-188}$ induces the dimerisation of the peptide [43].

Metal ions have been suggested to induce aggregation of amyloid beta-peptide, which is a key event in Alzheimer's disease [44]. Although, histidine-containing peptide fragments of prion protein are efficient ligands to bind various transition metal ions with the following order of metal affinity [45]: $\mathrm{Pd}$ (II) $>>\mathrm{Cu}$ (II) $>>\mathrm{Ni}$ (II) $\geq \mathrm{Zn}$ (II) $>\mathrm{Cd}$ (II) $\sim \mathrm{Co}$ (II) $>\mathrm{Mn}$ (II), our study showed the nickel was bound by $A \beta$ with higher affinity than copper ions. The high selectivity of metal binding is connected to the involvement of both imidazole and amide nitrogen atoms in metal binding for various metal ions [45].

Our results showed that $A \beta$ peptide is helical in hydrophobic environments and becomes mostly $\beta$-sheet in aqueous media or in the presence of some metal ions, which is concordant with Lau et al. [46]. Glycine residues in AB1-40 may be important in metal binding because they allow an appropriate folding of the peptide. Indeed, the GxxxG motifs of $A B$ is a key structural and functional determinant [47]. Besides, $\beta$-amyloid protein oligomers induced by metal ions and acid $\mathrm{pH}$ are distinct from those generated by slow spontaneous ageing at neutral $\mathrm{pH}$, as previously shown [48].

The three techniques used here (ESI-MS, CD, and AFM) revealed the complex interaction between $A \beta 1-40$ peptide with various metal ions under different $\mathrm{pH}$ conditions, with possible impact on the research methodology in various pathologies.

\section{Conclusions}

We have reported here a complex pattern of metal-metal competition for $A \beta 1-40$ binding sites, which depend essentially on the involved metal ions, their concentration, and $\mathrm{pH}$ changes. Thus, metal ions bind specifically to $A \beta 1-40$ peptide and change dramatically its conformation. Increasing $\mathrm{pH}$ results in increasing metal ions by $A \beta$. Significant copper and zinc bind to $A B 1-40$ peptide at $\mathrm{pH} 5.5$. However, up to three nickel ions commonly bind to each molecule of $\beta$-amyloid peptide, whereas the complex of $A \beta 1-40$ with four nickel ions was also confirmed by low signals at $\mathrm{m} / \mathrm{z} 760.6(6+)$ and $652.1(7+)$. In addition, nickel ions proved to enhance $A B$ oligomerization. Nevertheless, with increasing $\mathrm{pH}$, up to 12 ions of zinc may bind to a single $A \beta$ molecule. Both silver and iron ions displayed different binding patters as compared to the other investigated metal ions. $A B 1-40$ peptide without one molecule of water proved to bind easily eight silver ions to form an $A B$ complex that displayed specific signals in the MS spectrum at $\mathrm{m} / \mathrm{z}$ 1034.5. Iron(III) ions produced both the oligomerization of the peptide and the formation of iron-rich peptide complexes. Under the same $\mathrm{pH}$ and concentration conditions, the binding pattern of the independent copper and silver ions to $A \beta 1-40$ was different from that of the equimolecular mixture of the two metal ions. Maybe, some conformational changes due to water loss altered the capacity of $A B$ peptide to bind certain heavy metal ions. As a consequence, copper-silver interaction with the binding process to $A B 1-40$ was highly complex. $A$ competition between silver and nickel ions at high $\mathrm{pH}$ for $\mathrm{AB1}-40$ binding sites was also observed. New strategies were proposed to identify the characteristic signals for some important metal ion-peptide complexes in the spectra recorded at high $\mathrm{pH}$ or high metal concentrations. Unlike the current spectra of peptides or metal ion-peptide complexes at neutral $\mathrm{pH}$, each group of signals in a given area of the spectrum of high metal ion-peptide complexes at higher pH cannot be assigned to an isotopic distribution but many individual complexes. To explain the formation of such a large number of high metal-A $\beta$ complexes, we took into consideration the participation of both histidine residues and free amino group as well as carboxylate ones in the binding process. Circular dichroism and atomic force microscopy studies supported the mass spectrometric data.

Further research is needed to clarify the significance of multiple interactions of metal ions with $A B 1-40$ at various $\mathrm{pH}$ values for $A D$ pathology.

\section{Acknowledgements}

The financial support by PNII Partnership Biometac, Contract 32$173 / 2008$, as well as CNCSISS $2225 / 2009$ and ID-981 is gratefully acknowledged.

\section{References}

[1] P. Hut, J.A. Loo, Gas-phase coordination properties of $\mathrm{Zn}^{2+}, \mathrm{Cu}^{2+}, \mathrm{Ni}^{2+*}$, and $\mathrm{Co}^{2+}$ with histidine-containing peptides, J. Am. Chem, Soc. 117 (1995) 11314-11319.

[2] S. Zirah, S. Rebuffat, S.A. Kozin, P. Debey, F. Fournier, D. Lesage, J.C. Tabet, Zinc binding properties of the amyloid fragment Abeta(1-16) studied by electrosprayionization mass spectrometry, Int. J. Mass Spectrom. 228 (2003) 999-1016.

[3] P.A. Adlard, A.I. Bush, Metals and Alzheimer's disease, J. Alzheimer's Dis. 10 (2006) 145-163.

[4] A.I. Bush, The metallobiology of Alzheimer's disease. Trends Neurosci. 26 (2003) 207-214

[5] K.J. Barnham, C.L. Masters, A.l. Bush, Neurodegenerative diseases and oxidative stress, Nat. Rev, Drug Discov. 3 (2004) 205-214.

[6] C.J. Maynard, A.I. Bush, C.L. Masters, R. Cappai, Q.X. Li, Metals and amyloid-beta in Alzheimer's disease, int. J. Exp. Pathol. 86 (2005) 147-159.

[7] D.G. Smith, R. Cappai, K.J. Barnham, The redox chemistry of the Alzheimer's disease amyloid- $\beta$ peptide, BBA-Biomembranes 1768 (2007) 1976-1990.

[8] D.K. Lahiri, D.M. Chen, P. Lahiri, S, Bondy, N.H. Greig, Amyloid, cholinesterase, melatonin and metals, and their roles in aging and neurodegenerative diseases, Ann. N.Y. Acad. Sci. 1056 (2005) 430-449.

[9] R.J. Scheibe, H. Kuehl, S. Krautwald, J.D. Meissner, W.H. Mueller, Ecto-alkaline phosphatase activity identified at physiological pH range on intact P19 and HL-60 cells is induced by retinoic acid, J. Cell. Biochem. 76 (2000) 420-436,

[10] T.L. Lau, J.D. Gehman, J.D. Wade, C.L. Masters, K.J. Barnham, F. Separovic, Cholesterol and clioquinol modulation of $A \beta(1-42)$ interaction with phospholipid bilayers and metals, BBA-Biomembranes 1768 (2007) 3135-3144.

[11] C.S. Atwood, R.C. Scarpa, X. Huang, R.D. Moir, W.D. Jones, D.P. Fairlie, R.E. Tanzi, A.l, Bush, Characterization of copper interactions with Alzheimer amyloid $B$ peptides: identification of an attomolar-affinity copper binding site on amyloid $31-42$, J. Neurochem. 75 (2000) 1219-1233.

[12] J.Y. Lee, T.B. Cole, R.D. Paimiter, S.W. Suh, J.Y. Koh, Proc. Contribution by synaptic zinc to the gender-disparate plaque formation in human Swedish mutant APP transgenic mice, Natl. Acad. Sci. U. S. A. 99 (2002) 7705-7710.

[13] R.D. Terry, The pathogenesis of Alzheimer disease: an alternative to the amyloid hypothesis, J. Neuropathol. Exp. Neurol. 55 (1996) 1023-1025.

[14] X. Huang, C.S. Atwood, R.D. Moir, M.A. Hartshorn, J.P. Vonsattel, R.E. Tanzi, A.I. Bush, Zinc-induced Alzheimer's Abeta(1-42) aggregation is mediated by conformational factors, J. Biol. Chem. 272 (1997) 26464-26470.

[15] M.A. Lovell, C. Xie, W.R. Markesbery, Protection against amyloid beta peptide toxicity by zinc, Brain Res, 823 (1999) 88-95.

[16] C.S. Atwood, R.D. Moir, X. Huang, R.C. Scarpa, N.M.E. Bacarra, D.M. Romano, M.A. Hartshorn, R.E. Tanzi, A.l. Bush, Dramatic aggregation of Alzheimer A by Cu(II) is induced by conditions representing physiological acidosis, J. Biol. Chem. 273 (1998) 12817-12826

[17] D. Drago, M. Bettella, S. Bolognin, L Cendron, J. Scancar, R. Milacic, F. Ricchelli, A. Casini, L Messori, G. Tognon, P. Zatta, Potential pathogenic role of beta-amyloid(1-42)-aluminum complex in Alzheimer's disease, Int. . Biochem. Cell Biol. 40 (2008) 731-746.

[18] C.D. Syme, J.H. Viles, Solution ${ }^{7} \mathrm{H}$ NMR investigation of $\mathrm{Zn}^{2+1}$ and $\mathrm{Cd}^{2+}$ binding to amyloid-beta peptide $(A \beta)$ of Alzheimer's disease, BBA-Proteins Proteom 1764 (2006) 246-256

[19] C.C. Curtain, F. Ali, I. Volitakis, R.A. Cherny, R.S. Norton, K. Beyreuther, C.J. Barrow, C. Masters, A.I. Bush, K. Alzheimer's disease amyloid-b binds $\mathrm{Cu}$ and $\mathrm{Zn}$ to generate an allosterically ordered membrane-penetrating structure containing SoD-like subunits, J. I. Biol. Chem. 276 (2001) 20466-20473.

[20] A.R. White, K.J. Barnham, X. Huang, I. Voltakis, K. Beyreuther, C.I. Masters, R.A Cherny, A.I. Bush, R. Cappai, Iron inhibits neurotoxicity induced by trace copper and biological reductants, J. Biol. Inorg. Chem. 9 (2004) 269-280

[21] T. Jayasena, R.S. Grant, N. Keerthisinghe, I. Solaja, G.A. Smythe, Membrane permeability of redox active metal chelators: an important element in reducin hydroxyl radical induced $\mathrm{NAD}^{+}$depletion in neuronal cells, Neurosci. Res. 57 (2007) 454-461.

[22] S.Z. Wang, Y. Chen, Z.H. Sun, Q. Zhou, S.F. Sui, Escherichia coli CorA periplasmic domain functions as a homotetramer to bind substrate, J. Biol. Chem. 281 (2006) 26813-26820

[23] G. Schlosser, R. Stefanescu, M. Przybylski, M. Murariu, F. Hudecz, G. Drochioiu, Copper-induced oligomerization of peptides: a model study, Eur. J. Mass Spectrom 13 (2007) $331-337$. 
[24] M. Murariu, E.S. Dragan, G. Drochioiu, Synthesis and mass spectrometric characterization of a metal-affinity decapeptide: copper-induced conformational alterations, Biomacromolecules 8 (2007) 3836-3841.

[25] K. Popa, M. Murariu, G. Schlosser, R. Molnar, A. Cecal, G. Drochioiu, Effect of radioactive and non-radioactive mercury on wheat germination and the anti-toxic role of glutathione, Isot. Environ. Health Stud. 2 (2007) 105-116.

[26] G. Drochioiu, E.N. Damoc, M. Przybylski, Novel UV assay for protein determination and the characterization of copper-protein complexes by mass spectrometry, Talanta 69 (2006) 556-564.

[27] G. Drochioiu, M. Murariu, B.A. Petre, M. Manea, M. Przybylski, Synthesis and characterization of a nonapeptide with specific Cu-binding properties, Rev, Chim. (Bucharest) 58 (2007) 311-315

[28] R. Gradinaru, M. Murariu, E.S. Dragan, G. Drochioiu, Protein determination based on the biuret absorbtion in the UV range and copper binding to peptides, Roum. Biotechnol. Lett. 12 (2007) 3235-3239.

[29] D.P. Smith, D.G. Smith, C.C. Curtain, J.F. Boas, J.R. Pilbrow, G.D. Ciccotosto, T.L. Lau, D.] Tew, K. Perez, J.D. Wade, A.I, Bush, S.C, Drew, F, Separovic, C.L, Masters, R, Cappai, K.J. Barnham, Coppermediated amyloid-toxicity is associated with an intermolecular histidine bridge, J. Biol. Chem. 281 (2006) 15145-15154.

[30] C.D. Syme, R.C. Nadal, S.E.J. Rigby, J.H. Viles, Copper binding to the amyloid-\{beta\} (a[beta) peptide associated with Alzheimer's disease: folding, coordination geometry, pH dependence, stoichiometry, and affinity of A(beta\}-(1-28): insights from a range of complementary sectroscopic techniques, J. Biol. Chem. 279 (2004) 18169-18177

[31] J.W. Karr, H. Akintoye, L.] Kaupp, V.A. Szalai, N-Terminal deletions modify the Cu2+ binding site in amyloid- $\beta$, Biochemistry 44 (2005) 5478-5487.

[32] J.W. Karr, LJ. Kaupp, V.A. Szalai, Amyloid-ßB binds copper(II) in a mononuclear metal ion binding site, J. Am. Chem. Soc, 126 (2004) 13534-13538.

[33] D. Lagadic-Gossmann, L. Huc, V. Lecureur, Alterations of intracellular pH homeostasis in apoptosis: origins and roles. Cell Death Differ. 11 (2004) 953-961.

[34] D. Chappell, K. Hofmann-Kiefer, M. Jacob, P. Conzen, M. Rehm, Metabolic alkalosis despite hyperlactatemia and hypercapnia: interpretation and therapy with help of the Stewart concept, Anaesthesist 57 (2008) 139-142.

[35] M. Aoki, F. Nomura, M.E. Stromski, M.K. Tsuji, J.C, Fackler. P.R. Hickey, D.H, Holtzman, R.A. Jonas, Effects of pH on brain energetics after hypothermic circulatory arrest, Ann. Thorac, Surg. 55 (1993) $1093-1103$.

[36] C.M. Yates, J. Butterworth, M.C. Tennant, A. Gordon, Enzyme activities in relation to $\mathrm{pH}$ and lactate in postmortem brain in Alzheimer-type and other dementias, J. Neurochem. 55 (2006) 1624-1630.
[37] R.E. Anderson, FB, Meyer, Is intracellular brain pH a dependent factor in NOS inhibition during focal cerebral ischemia? Brain Res. 856 (2000) 220-226.

[38] Hanson, K.C. Stokes, M. Leopold, G. Multhaup, LE. Goldstein, R.C. Scarpa, A.] Saunders, J. Lim, R.D. Moir, C. Glabe, E.F. Bowden, C.L Masters, D.P. Fairlie, R.E. Tanzi, A.I. Bush, Cu(II) potentiation of Alzheimer Abeta neurotoxicity. Correlation with cell-free hydrogen peroxide production and metal reduction, ]. Biol, Chem 274 (1999) 37111-37116.

[39] A.K. Tickler, A.B. Clippingdale, J.D. Wade, Amyloid-b as a 'difficult sequence' in solid phase peptide synthesis, Protein Pept. Lett, 11 (2004) 377-384.

[40] O.N. Antzutkin, Amyloidosis of Alzheimer's Abeta peptides: solid-state nuclea magnetic resonance, electron paramagnetic resonance, transmission electron microscopy, scanning transmission electron microscopy and atomic force microscopy studies, Magn. Reson, Chem. 42 (2004) 231-246.

[41] D.S. Yang, J.A. McLaurin, K. Qin, D. Westaway, P.E. Fraser, Examining the zinc binding site of the amyloid-beta peptide, FEBS J. 267 (2000) 6692-6698.

[42] S. Zirah, S.A. Kozin, A.K. Mazur, A. Blond, M. Cheminant, I. Ségalas-Milazzo, P. Debey, S. Rebuffat, Structural changes of region 1-16 of the Alzheimer disease amyloid beta-peptide upon zinc binding and in vitro aging, J. Biol. Chem. 281 (2006) 2151-2161.

[43] E.D. Ciuculescu, Y. Mekmouche, P. Faller, Metal-binding properties of the peptide APP170-188: a model of the ZnIl-binding site of amyloid precursor protein (APP). Chem-Eur. J. 11 (2004) 903-909.

[44] T. Miura, S. Mitani, C. Takanashi, N. Mochizuki, Copper selectively triggers betasheet assembly of an N-terminally truncated amyloid beta-peptide beginning with Glu3, J, Inorg. Biochem. 98 (2004) 10-14

[45] V. Jószai, N, Nagy, K, Ôsz, D. Sanna, G. Di Natale, D. La Mendola, G. Pappalardo, G. Rizzarelli, I. Sóvágó. Transition metal complexes of terminally protected peptides containing histidyl residues, J. Inorg. Biochem. 100 (2006) 1399-1409.

[46] T.L. Lau, J.K. Barnham, C.C. Curtain, C.L. Masters, F. Separovic, Magnetic resonance studies of -amyloid peptides, Aust. J. Chem. 56 (2003) 343-348.

[47] Y. Xu, J. Shen, X. Luo, W. Zhu, K, Chen. J. Ma, H. Jiang, Conformational transition of amyloid (beta) peptide, Proc. Natl. Acad. Sci. U. S. A. 102 (2005) 5403-5407.

[48] G.M. Klug, D. Losic, S.S. Subasinghe, M.I. Aguilar, L.L. Martin, D.H. Small, Betaamyloid protein oligomers induced by metal ions and acid $\mathrm{pH}$ are distinct from those generated by slow spontaneous ageing at neutral pH, Eur. J. Biochem, 270 (2003) 4282-4293. 